\title{
AMORPHIZATION AND STRESS IN ION-IMPLANTED CRYSTALLINE SOLIDS
}

\author{
D. Girdauskiené ${ }^{\mathrm{a}}$ and I. Požèla ${ }^{\mathrm{b}}$ \\ ${ }^{a}$ Department of Physics, Lithuanian University of Agriculture, Universiteto 10, LT-4324 Kaunas, Lithuania \\ E-mail: daliag@info.lzua.lt \\ ${ }^{\mathrm{b}}$ Department of Physics, Kaunas University of Technology, Studentu 50, LT-51424 Kaunas, Lithuania
}

Received 14 October 2003

Dedicated to the 100th anniversary of Professor K. Baršauskas

\begin{abstract}
The model of amorphization of crystals induced by ion irradiation is considered. The model describes two stages of the amorphization, the generation of primary defects by collision cascades and the collapse of crystalline regions, which begins when the concentration of the primary defects reaches about $10 \%$. Due to the colapse of crystalline regions, the total defect concentration increases up to about $80 \%$ for rather small increment of the fluence $\Phi$. The defect concentration and the integral stress were calculated theoretically for the silicon samples subjected to irradiation with light, average, and heavy mass ions. The integral stress was analysed as the sum $S=S_{\mathrm{d}}+S_{\text {ion }}$, where the $S_{\mathrm{d}}$ and $S_{\text {ion }}$ terms correspond to the stresses due to point defects and implanted ions, respectively. At low fluences, $\Phi<\Phi_{\mathrm{a}}$ (where $\Phi_{\mathrm{a}}$ is the characteristic amorphization fluence), the term $S_{\mathrm{d}}$ linearly depends on the fluence and essentially exceeds the stress due to implanted ions. The integral stress acquires a maximum value at $\Phi=\Phi_{\mathrm{a}}$. At higher fluences, $\Phi>\Phi_{\mathrm{a}}$, the term $S_{\mathrm{d}}$ considerably decreases and the $S_{\mathrm{ion}}$ term dominates the integral stress. In this $\Phi$ region, the stress saturates to the constant value, which is larger for the lighter ions and smaller for the heavier ones.
\end{abstract}

Keywords: ion irradiation, defects, amorphization, integral stress, relaxation

PACS: 61.80.Jh, 62.40.+i

\section{Introduction}

Ion implantation is widely used for doping semiconductors and for their technological processing (see, e. g., [1]). Various aspects of the ion-bombardmentinduced amorphization, strain, and stress are considered in literature [2-7]. The stress and strain dependences on the irradiation fluence, the ion energy and mass, as well as the stress relaxation processes are the key problems considered. The stress in the crystalline silicon usually increases with the fluence of ion irradiation and the stress values up to $10^{8}-10^{9} \mathrm{~Pa}$ are achieved nearby the onset of amorphization. After an initial growth of stress in the ion-implanted layer, further irradiation is followed by the stress relaxation and a maximum in the stress versus fluence dependence is observed for many different ion-target combinations. With an increase of the ion mass the maximum usually shifts to the lower dose region $[8,9]$.

The in-plane stress for thin samples depends on the biaxial strain. On the other hand, strain in the perpendicular direction is usually measured experimentally
[10-12] and the Poisson relation is used [8] to determine the in-plane strain from the measured perpendicular strain values. It should be mentioned as well that the plastic flow of material can contribute to the in-plane strain when a crystal is saturated by radiation defects. The factors can affect the accuracy of strain determination, and to avoid the uncertainties a rigorous treatment of the in-plane stress is required.

In the present paper an algorithm for the defect concentration and the in-plane strain calculations is suggested which accounts for the amorphization and stress relaxation processes in ion-irradiated solids.

\section{The effect of fluence on amorphization in ion-implanted crystalline samples}

The ion-beam-induced amorphization can occur during bombardment with the light, average, and heavy mass ions. The ions accelerated up to the $\mathrm{keV}$ or $\mathrm{MeV}$ energy dispose a considerable amount of their energy to target atoms. The energy released results in the forma- 
tion of point defects (Frenkel pairs) and their clusters in the crystalline matrix.

The Rutherford backscattering channelling studies reveal two stages of defect formation scenario. The first stage corresponds to a low fluence $\Phi$, which leads to accumulation of point defects in the crystalline matrix and to slow increase of the defect concentration with an increase of $\Phi[5,13,14]$. In the second stage, which sets up when the fluence exceeds its definite critical value, the concentration of defects steeply increases from about $10 \%$ up to approximately $80 \%$ in the fairly narrow region of fluence [3,15]. This indicates that the formation of defects in a predamaged matrix is more efficient than in a virgin crystal and suggests that the newly produced defects destabilize the crystal and cause the formation of expanding disordered zones. Such a process induces about eight times larger displacements as compared with those due to the direct collisions of incident ions with target atoms. The amorphization process can be related with a collapse of crystalline zones. The zones surrounded by expanding disordered clusters experience substantial compression and deformation of their lattices [3,15-17]. The lattice compression can be related to shifts of an interface between the crystal and amorphous phases $[4,6]$ and can be followed by the thermal spikes $[16,17]$.

To model the strained lattice we consider the displaced atoms and their initial node positions as the defect pairs. The "displaced atom plus vacancy node" defects are generated not only during the lattice collapse, but during recombination of Frenkel pairs as well. On the basis of the accelerated growth of damage observed, we suggest the phenomenological model of the damage build-up assuming that the generation rate of the stable defects is proportional to the concentration $C$ of the existing ones,

$$
\frac{\mathrm{d} C}{\mathrm{~d} \Phi}=\frac{F_{n}(1-C)}{n_{0}}+\frac{\alpha C}{j}-\frac{\beta n_{0} C^{2}}{j} .
$$

Here $F_{n}$ is the number of irradiation-created defects per unit layer, $n_{0}$ is the particle density in a crystal, $j$ is the ion flux, and $\alpha$ and $\beta$ are phenomenological parameters. The first term in the right-hand side of Eq. (1) describes the generation rate in the cascades of elastic collisions, the second term describes the collapse of the crystalline zones, and the third one corresponds to the recombination of defects.
Equation (1) should be solved with the boundary conditions

$$
\begin{gathered}
C(\Phi \rightarrow 0)=0 \\
C(\Phi \rightarrow \infty)=1 \\
\left.\frac{\mathrm{d} C}{\mathrm{~d} \Phi}\right|_{\Phi \rightarrow \infty}=0,
\end{gathered}
$$

which set up the following relation between parameters $\alpha$ and $\beta$ :

$$
\alpha=\beta n_{0} .
$$

The straightforward solution of Eq. (1) with account of Eqs. (2) and (3) yields the following formula for the defect concentration:

$$
C=\frac{1-\mathrm{e}^{-\left(1+C_{0}\right) \Phi / \Phi_{0}}}{1+C_{0}^{-1} \mathrm{e}^{-\left(1+C_{0}\right) \Phi / \Phi_{0}}},
$$

where $C_{0} \equiv F_{n} j /\left(\alpha n_{0}\right)$ and $\Phi_{0} \equiv j / \alpha$.

\section{Stress in ion-implanted crystals}

Following the model of stress formation described in [18-21], we assume that the strain in the ion-implanted surface layer is due to the point defects, which correspond to the "displaced atom plus vacancy node" pairs. Let us denote the relative increment of the atomic volume due to the "vacancies" and displaced atoms as $\Delta \Omega_{\mathrm{V}} / \Omega$ and $\Delta \Omega_{\mathrm{S}} / \Omega$, respectively, and the relative volume increment due to the implanted ions as $\Delta \Omega_{\text {ion }} / \Omega$. Here $\Omega$ is the atomic volume of the considered crystal. (Under usual conditions $\left|\Delta \Omega_{\mathrm{v}}\right|<\Delta \Omega_{\mathrm{s}}$.)

The point defects generated by ion irradiation induce the local expansion of the lattice. It should be noted that the expansion depends both on the concentration of the point defects $C$ and on the concentration of implanted ions $C_{\text {ion }}$. Therefore, the in-plane components of the strain tensor $\varepsilon_{11}^{*}=\varepsilon_{22}^{*}=\varepsilon_{\mathrm{in}}^{*}$ can be presented in the following form:

$$
\varepsilon_{\mathrm{in}}^{*}=\frac{1}{3}\left(C \frac{\Delta \Omega_{\mathrm{d}}}{\Omega}+C_{\mathrm{ion}} \frac{\Delta \Omega_{\mathrm{ion}}}{\Omega}\right),
$$

where $\Delta \Omega_{\mathrm{d}} / \Omega=\Delta \Omega_{\mathrm{S}} / \Omega-\left|\Delta \Omega_{\mathrm{v}}\right| / \Omega$.

The concentration of implanted ions can be presented as $C_{\text {ion }}=F_{\text {ion }}\left(x_{3}\right) \Phi / n_{h}$, where the $F_{\text {ion }}\left(x_{3}\right)$ function describes the ion distribution profile along $x_{3}$ axis, and $n_{h}$ is the interstitial cavity density. 
Table 1. Values of the parameters $C_{0}, \Phi_{0}, \Phi_{\mathrm{r}}$, and $\Phi_{\mathrm{a}}$ used for calculation of the defect concentration and of the integral stress.

\begin{tabular}{ccccc}
\hline Ion & $\begin{array}{c}C_{0}, \\
10^{-2}\end{array}$ & $\begin{array}{c}\Phi_{0}, \\
10^{13} \mathrm{~cm}^{-2}\end{array}$ & $\begin{array}{c}\Phi_{\mathrm{r}}, \\
10^{14} \mathrm{~cm}^{-2}\end{array}$ & $\begin{array}{c}\Phi_{\mathrm{a}}, \\
10^{14} \mathrm{~cm}^{-2}\end{array}$ \\
\hline $\mathrm{Xe}$ & 6.1 & 0.8 & 1 & 0.4 \\
$\mathrm{Ar}$ & 9.4 & 7.7 & 3 & 2 \\
$\mathrm{Ne}$ & 28 & 90 & 13 & 30 \\
$\mathrm{He}$ & 38 & 3000 & 45 & - \\
\hline
\end{tabular}

The planar stress $\sigma_{11}=\sigma_{22}=\sigma_{\text {in }}$, which settles down in a sample, is determined by the BoltzmannVolterra's integral equation [22]

$$
\sigma_{\mathrm{in}}=-\frac{Y}{1-\nu}\left[\varepsilon_{\mathrm{in}}^{*}(\Phi)-\int_{0}^{\Phi} \Gamma\left(\Phi-\Phi^{\prime}\right) \varepsilon_{\mathrm{in}}^{*}\left(\Phi^{\prime}\right) \mathrm{d} \Phi^{\prime}\right],
$$

where $Y$ is Young's modulus and $\nu$ is the Poisson coefficient. Within the framework of the Maxwell model, the kernel of integral transformation (6) for the viscoelastic medium acquires the exponential form $\Gamma(\Phi)=\Phi_{\mathrm{r}}^{-1} \exp \left(-\Phi / \Phi_{\mathrm{r}}\right)$, where $\Phi_{\mathrm{r}}=6(1-\nu) j \eta / Y$ is the characteristic fluence of relaxation and $\eta$ is the viscosity of the material.

The integral stress in the ion-implanted layer $S=$ $\int_{0}^{\delta} \sigma_{\text {in }}\left(x_{3}\right) \mathrm{d} x_{3}$, where $\delta$ is the layer thickness, is convenient to present as a sum of two components, $S=$ $S_{\mathrm{d}}+S_{\text {ion. }}$. Here $S_{\mathrm{d}}$ is the integral stress due to the point defects and $S_{\text {ion }}$ is the stress due to implanted atoms. Taking into account the normalization condition $\int_{0}^{\delta} F_{\text {ion }}\left(x_{3}\right) \mathrm{d} x_{3}=1$, the following formulas for the $S_{\mathrm{d}}$ and $S_{\text {ion }}$ stress components can be derived from Eqs. (5) and (6):

$$
\begin{aligned}
S_{\mathrm{d}}= & \frac{Y \delta}{3(1-\nu)} \frac{\Delta \Omega_{\mathrm{d}}}{\Omega} \\
& \times\left[C-\frac{\mathrm{e}^{-\Phi / \Phi_{\mathrm{r}}}}{\Phi_{\mathrm{r}}} \int_{0}^{\Phi} C \mathrm{e}^{-\Phi^{\prime} / \Phi_{\mathrm{r}}} \mathrm{d} \Phi^{\prime}\right], \\
S_{\text {ion }}= & \frac{Y \Phi_{\mathrm{r}}}{3(1-\nu) n_{h}} \frac{\Delta \Omega_{\text {ion }}}{\Omega}\left(1-\mathrm{e}^{-\Phi / \Phi_{\mathrm{r}}}\right) .
\end{aligned}
$$

\section{Results and discussion}

Let us calculate the concentration of defects in the crystalline silicon induced by irradiation with the light $(\mathrm{He})$, average ( $\mathrm{Ne}, \mathrm{Ar})$, and heavy $(\mathrm{Xe})$ mass ions. We choose the parameters $C_{0}$ and $\Phi_{0}$ (Table 1) of the problem such that the characteristic steep increase of the defect concentration $C$ would correspond to the amorphization fluence $\Phi_{\mathrm{a}}$, the experimental values of which are presented in $[3,23]$.

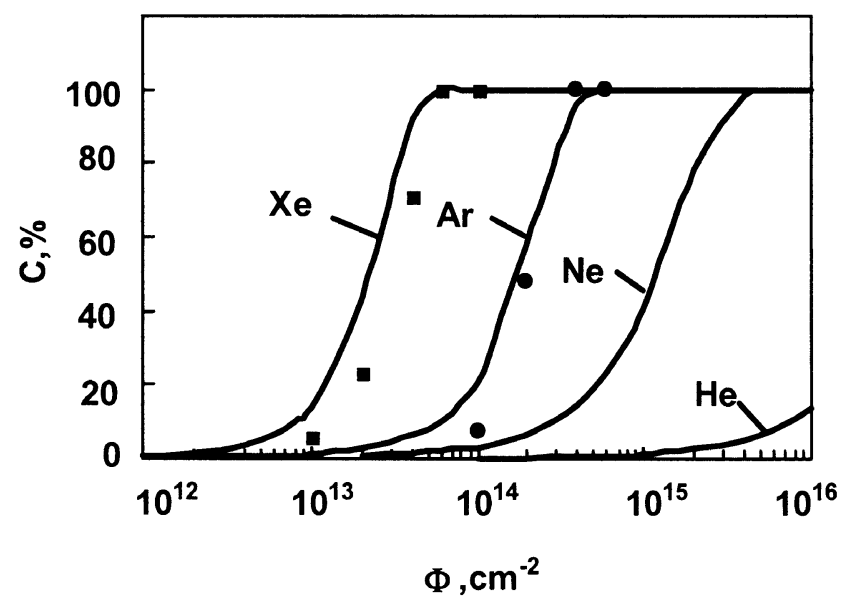

Fig. 1. The dependence of the calculated concentration of defects in silicon on the fluence of ion irradiation. Dots present the experimental values [3] recorded at the ion flux $\leq 0.5 \mu \mathrm{A} / \mathrm{cm}^{2}$ and the ion energy of $570 \mathrm{keV}(\mathrm{Xe})$ and $250 \mathrm{keV}(\mathrm{Ar})$.

The results of calculations are presented in Fig. 1. As seen, there are several regimes of the $C$ versus $\Phi$ dependence. At the low fluence, $\Phi<0.1 \Phi_{\mathrm{a}}$, the defect concentration linearly increases with the fluence, following the law $C=C_{0} \Phi / \Phi_{0}=F_{n} \Phi / n_{0}$, which can be derived as an asymptotical solution of Eq. (4). When the fluence enters the $0.1 \Phi_{\mathrm{a}}<\Phi<\Phi_{\mathrm{a}}$ range, the concentration of defects increases superlinearly, more rapidly, though the $C$ values remain below $20 \%$ and indicate a preamorphous phase. At the $\Phi$ values close to the amorphization fluence, $\Phi \approx \Phi_{\mathrm{a}}$, the concentration of defects steeply increases up to about $80 \%$ indicating the amorphization by a collapse of crystalline zones. The further increase of the fluence, $\Phi>\Phi_{\mathrm{a}}$, is followed by the slow increase of the concentration, described by the $C \approx 1-C_{0} \exp \left(-\Phi / \Phi_{0}\right)$ law.

The amorphization fluence depends on the mass of ions. In the case of heavy mass ions, each ion is believed to produce, via kinematic collisions, a localized densily defected region which is unstable and collapses to an amorphous zone. The average mass ions produce the lower defect density region, and successive impacts within the region are required to increase the local defect concentration until the collapse takes place. Therefore, the amorphization of a sample irradiated by the lighter ions occurs at higher $\Phi$ values. For example, the amorphization fluence $\Phi_{\mathrm{a}} \approx 3 \cdot 10^{15} \mathrm{~cm}^{-2}$ for the $\mathrm{Ne}$ ion irradiation is about 70 times larger than that for $\mathrm{Xe}$ ions, $\Phi_{\mathrm{a}} \approx 0.4 \cdot 10^{14} \mathrm{~cm}^{-2}$. The light ions (He) create the smallest number of primary defects in the cascades of elastic collisions, and the He-induced Si amor- 
phization is not observed even at the rather high fluences of $10^{16} \mathrm{~cm}^{-2}$.

Now let us consider the irradiation-induced stress in the $\operatorname{Si}(111)$ sample. To calculate the integer stress defined by Eqs. (7) and (8), one needs to determine the relative volume increments due to the point defects and implanted atoms. The value of the first parameter can be taken from literature data $[3,24], \Delta \Omega_{\mathrm{d}} / \Omega=0.02$, while for evaluation of the second one the following formula [25] can be used:

$$
\frac{\Delta \Omega_{\mathrm{ion}}}{\Omega}=\left(\frac{r_{\mathrm{ion}}}{r_{\mathrm{h}}}\right)^{3}-1 .
$$

Here $r_{\text {ion }}$ and $r_{\mathrm{h}}$ are the ion and interstitial vacancy radii, respectively.

The following values of parameters were used in calculations: $r_{\text {ion }}[\mathrm{He}]=54 \mathrm{pm}, r_{\text {ion }}[\mathrm{Ne}]=130 \mathrm{pm}$, $r_{\text {ion }}[\mathrm{Ar}]=144 \mathrm{pm}, r_{\text {ion }}[\mathrm{Xe}]=170 \mathrm{pm} \mathrm{[26],} r_{\mathrm{h}}[\mathrm{Si}]=$ $52.5 \mathrm{pm}, Y_{\langle 111\rangle}=1.69 \cdot 10^{11} \mathrm{~Pa}, \nu=0.262$ [27], $n_{0}=5 \cdot 10^{28} \mathrm{~m}^{-3}$, and $n_{\mathrm{h}}=3.75 \cdot 10^{28} \mathrm{~m}^{-3}$. The range of implanted ions was calculated by the TRIM 91 algorithm [28].

The dependence of the integral stress on the fluence is presented in Fig. 2. At the low fluence, $\Phi \ll \Phi_{a}$, the stress is determined primarily by the defects created in collision cascades, $S_{\mathrm{d}} \gg S_{\text {ion }}$, and the linear dependence $S=A \Phi$ is observed, where the coefficient $A$ is determined by the expression

$$
A=\frac{Y F_{n} \delta}{3(1-\nu) n_{0}} \frac{\Delta \Omega_{\mathrm{d}}}{\Omega} .
$$

As seen from Fig. 2, the stress increases with an increase of the ion mass in the region of low fluences. The effect is due to the energy loss features and affects the stress via the density of defects $F_{n}$.

The stress acquires the maximum value at $\Phi=\Phi_{\mathrm{a}}$, i. e. when the sample amorphizes. Above the amorphization fluence, at $\Phi>\Phi_{\mathrm{a}}$, the stress noticeably relaxes, as clearly seen from Fig. 2. The relaxation is determined by the viscosity of a sample and by the density of radiation defects. The function $F_{n}$, which represents the density of radiation defects, acquires the highest values for the heavy ions and the peak in the stress versus fluence dependence occurs at lower fluences as compared to $S=S(\Phi)$ dependences of the average-mass and the light atoms ( $\mathrm{Ar}$ and $\mathrm{Ne}$ ). The defect density induced by the He irradiation is rather low and the stress does not reach maximum even at the fluences of $\sim 10^{16} \mathrm{~cm}^{-2}$.

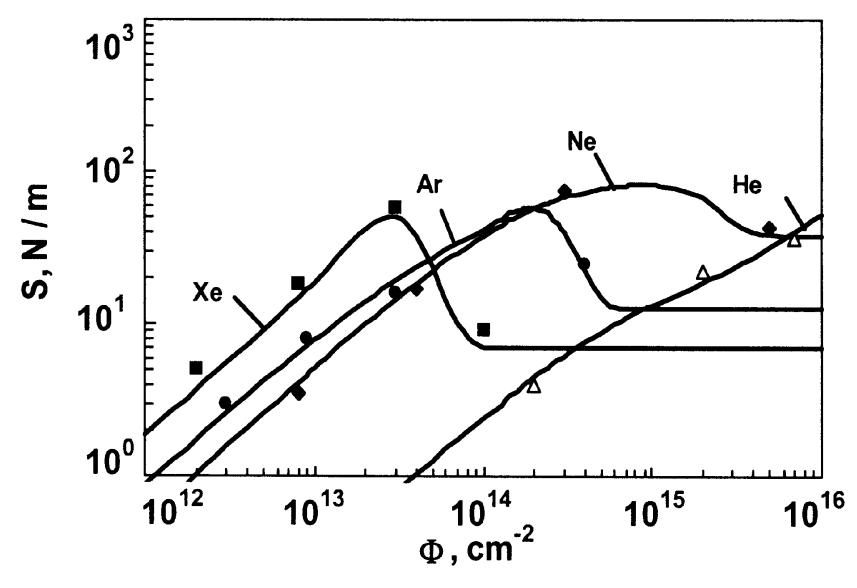

Fig. 2. The theoretical integral stress in silicon (111) versus the fluence of ion irradiation. Dots present the experimental values [27] recorded at the ion energy of $220 \mathrm{keV}$ and the flux of $1 \mu \mathrm{A} / \mathrm{cm}^{2}$.

At the high fluences, exceeding the characteristic relaxation fluence, $\Phi>\Phi_{\mathrm{r}}$, the stress $S_{\mathrm{d}}$, which is due to point defects, essentially decreases and the stress $S_{\text {ion }}$ due to implanted ions dominates the integral stress. The stress $S_{\text {ion }}$ depends on the relative increment of the atomic volume $\Delta \Omega_{\text {ion }} / \Omega$ and on the characteristic fluence of relaxation $\Phi_{\mathrm{r}}$. Though one can expect that the heavier ions should induce the higher stress, the parameter $\Phi_{\mathrm{r}}$ for lighter ions is larger (see Table 1). Therefore, in the region of high fluences, the integral stress induced by irradation with the light mass ions exceeds that induced by the heavy ones. An exception is $\mathrm{He}$ - the stress due to implanted He ions is not significant, because the ion radius of $\mathrm{He}$ is rather close to the radius of an interstitial cavity.

In summary, we conclude that the proposed theoretical model correctly describes the main features of the amorphization and the integral stress in ion-irradiated crystals, and the calculated dependences of the defect concentration and integral stress on the ion fluence nicely fits the experimental data recorded for the ionimplanted silicon samples.

\section{References}

[1] E. Chason, S.T. Picraux, J.M. Poate, J.O. Borland, M.I. Current, T. Diaz de la Rubia, D.J. Eaglesham, O.W. Holland, M.E. Law, C.W. Magel, J.W. Mayer, J. Meingailis, and A.F. Tasch, Ion beams in silicon processing and characterization, J. Appl. Phys. 81(10), 6513-6561 (1997).

[2] G. Carter, The effects of flux, fluence and temperature on amorphization in ion implanted semiconductors, J. Appl. Phys. 79(11), 8285-8289 (1996). 
[3] G. Bai and M.-A. Nicolet, Defect production in $\mathrm{Si}(100)$ by $\mathrm{F}, \mathrm{Si}, \mathrm{Ar}$ and $\mathrm{Xe}$ implantation at room temperature, J. Appl. Phys. 70(7), 3521-3555 (1991).

[4] T. Henkel, V. Heera, R. Kögler, and W. Skorupe, Kinetics of ion-beam-induced interfacial amorphization in silicon, J. Appl. Phys. 82(11), 5360-5373 (1977).

[5] A. Battaglia and S.U. Campisano, Mechanisms of amorphization of crystalline silicon, J. Appl. Phys. 74(10), 6058-6061 (1993).

[6] Yu. Suprun-Belevich, F. Cristiano, A. Nejim, P.L.F. Hemment, and B.J. Sealy, Mechanical strain and defects in the end-of-range region in silicon implanted with $\mathrm{C}^{+}$ions, Semicond. Sci. Techol. 13, 220-225 (1998).

[7] V.V. Bolotov, M.D. Efremov, and V.A. Volodin, Mechanical stress relaxation in ion-implanted SOS structures, Thin Solid Films 248, 212-219 (1994).

[8] C.A. Volkert, Stress and plastic flow in silicon during amorphization by ion bombardment, J. Appl. Phys. 70(7), 3521-3527 (1994).

[9] L. Pranevičius, S. Tamulevičius, L. Puodžiukynas, and A. Matiukas, Application of laser interferometer systems for the study of ion interaction with solid, Phys. Status Solidi 96, K157-K161 (1986).

[10] K.F. Badawi, P.H. Coudeau, J. Pacaud, C. Jaouen, J. Delafand, A. Naudou, and G. Gladyszewski, X-ray diffraction study of residual stress modification in $\mathrm{Cu} / \mathrm{W}$ superlattices irradiated by light and heavy ions, Nucl. Instrum. Methods Phys. Res. B 80/81, 404-407 (1993).

[11] Z.E. Horvath, G. Peto, E. Zsoldos, and J. Gyalai, Strain in $\mathrm{As}^{+}$and $\mathrm{Sb}^{+}$implanted and annealed $\langle 100\rangle \mathrm{Si}$, Nucl. Instrum. Methods Phys. Res. B 80/81, 552-555 (1993).

[12] B.B. Sharma, S.R. Gupta, V. Kumar, U. Tiwari, P. Sen, and G.K. Mehta, XRT mapping of strain induced by $200 \mathrm{MeV} \mathrm{Ag}^{14+}$ ions in $\mathrm{Si}(001)$, Mater. Chem. Phys. 54, 293-295 (1998).

[13] J. Dennis and E.B. Hale, Crystalline to amorphous transformation in ion-implanted silicon: A composite model, J. Appl. Phys. 49(3), 1119-1127 (1978).

[14] H. Trinkaus, Ion beam induced amorphisation of crystalline solids: Mechanisms and modelling, Mater. Sci. Forum 248, 3-12 (1997).
[15] G. Bai and M.-A. Nicolet, Defects production and annealing in self-implanted Si, J. Appl. Phys. 70(2), 649-655 (1991).

[16] H. Trinkaus and A.I. Ryazanov, Viscoelastic model for the plastic flow of amorphous solids under energetic ion bombardment, Phys. Rev. Lett. 74(25), 5072-5075 (1995).

[17] S.G. Mayr, Y. Ashkenazy, and R.S. Averback, Evolution of thin-film morphologies during ion beam bombardment, Nucl. Instrum. Methods Phys. Res. B 212, 246-252 (2003).

[18] S. Tamulevičius and I. Požèla, Stress and strain in the ion implanted crystalline silicon, Materials Science (Medžiagotyra) 2(5), 32-34 (1997).

[19] S. Tamulevičius and I. Požèla, Dynamics of the integral stress and strain in the ion implanted silicon, in: Proc. of International Conference on Plasma Physics and Plasma Technology (PPPT-2) (Minsk, 1997).

[20] S. Tamulevičius, I. Požèla, and J. Jankauskas, Integral stress in ion-implanted silicon, J. Phys. D 31(7), 29912996 (1998).

[21] D. Girdauskienė and I. Požèla, Elastic stress in ionimplanted crystals of silicon, Lithuanian J. Phys. 39(1), 69-73 (1999).

[22] M. Bartenev and D. Sanditov, Relaxation Processes in Glass-like Systems (Nauka, Novosibirsk, 1986) [in Russian].

[23] L. Pranevičius and J. Dudonis, Ion Beam Modification of Solids (Mokslas, Vilnius, 1980).

[24] L.I. Fedina, On the recombination and the interaction of intrinsic point defects with the surface during point defect clustering in Si crystal, Fiz. Tekh. Poluprovodn. 35(9), 1120-1126 (2001).

[25] K.G. McQuhae and A.S. Brown, The lattice contraction coefficient of boron and phosphorus in silicon, Solid State Electron. 15, 259-264 (1972).

[26] T. Erdey-Gruz, Grundlagen der Struktur der Materie (Mir, Moscow, 1976).

[27] E.P. Eer Nisse, Sensitive technique for studying ionimplantation damage, Appl. Phys. Lett. 18(12), 581583 (1971).

[28] J.P. Biersack and L.G. Haggmark, A Monte Carlo computer program for the transport of energetic ions in amorphous targets, Nucl. Instrum. Methods Phys. Res. 174, 257-269 (1980). 


\title{
AMORFINIMASIS IR ITEMPIAI JONAIS ŠVITINAMUOSE KRISTALUOSE
}

\author{
D. Girdauskienè ${ }^{\mathrm{a}}$, I. Požèla ${ }^{\mathrm{b}}$ \\ ${ }^{a}$ Lietuvos žemès ūkio universitetas, Kaunas, Lietuva \\ ${ }^{\mathrm{b}}$ Kauno technologijos universitetas, Kaunas, Lietuva
}

\section{Santrauka}

Pateiktas modelis, aprašantis joninio švitinimo sukeltą kristalinio bandinio amorfizaciją ir paskaičiuoti jos sukelti radiaciniai ìtempiai. Modelis atitinka du gardelès amorfinimosi etapus: pirminių defektų (tarpmazgių, vakansijų, Frenkelio porų) kūrimą jonų arba atatrankos atomų dūžių santalkose ir kristalinių sričių gniuždymą (kolapsavima). Gardelès gniuždymas pradeda reikštis, kai pirminių defektų koncentracija pasiekia $\approx 10 \%$. Dèl to vyksmo siaurame apšvitų ruože defektų koncentracija padidejja iki $\approx 80 \%$. Apskaičiuota koncentracija defektų, sukurtu švitinant si- lici sunkiais $(\mathrm{Xe})$, vidutinès masès (Ar, $\mathrm{Ne}$ ) ir lengvais $(\mathrm{He})$ jonais. Darbe taip pat analizuojami tụ jonų silicyje sukurti integriniai įtempiai. Sukurti įtempiai yra gniuždantys ir lygūs $S=$ $S_{\mathrm{d}}+S_{\text {ion }}$. Ittempių sandas $S_{\mathrm{d}}$ sukurtas radiacinių taškinių defektų, $S_{\text {ion }}$ - itterptu jonų. Esant mažoms apšvitoms, $\Phi<\Phi_{\text {a }}$ (čia $\Phi<\Phi_{\mathrm{a}}-$ amorfinimosi apšvita), $S_{\mathrm{d}}$ sandas tiesiškai priklauso nuo apšvitos, o $S_{\text {ion }} \ll S_{\mathrm{d}}$. $S_{\mathrm{d}}$ yra didžiausias, jei $\Phi=\Phi_{\mathrm{a}}$, o $S_{\text {ion }}$ sandas vis dar nežymus. Toliau švitinant, $\Phi>\Phi_{\mathrm{a}}$, dydis $S_{\mathrm{d}}$ relaksuoja į nulį, o dydis $S_{\text {ion }}$ issisotina. $S_{\text {ion }}$ sandas didesnis lengvesniems jonams, mažesnis - sunkesniems. 